\title{
Social and Functional Significance of Language: Case Study with Reference to English and Tamil
}

\author{
K. Karunakaran* \\ Visting Professor, Department of Linguistics, Bharathiar University, Coimbatore, Tamil Nadu, \\ India; krishnamoorthykarunakaran32@gmail.com
}

\begin{abstract}
Language has two sides from the points of view of its structure and use since it has social and functional significance in its everyday application. The significance and relevance are interdependent, as one cannot think of a language without a society by which it is used, and vice versa. The functional aspect of language is imperative in the formal and informal contexts starting from the home domain. Mainly, there are two styles of language a human being possesses - 'careful speech style' and 'casual speech style' - which is chosen contextually. Language has a well defined structure but for a few exceptions. These structural similarities and distinctive variations/differences have to be explicitly made known to the learners especially in ELT or TLT.
\end{abstract}

Keywords: CALL, Cohesion, Coherence, Contextual Meaning, F-Fu-M Relationship, Lexical Meaning

\section{Introduction}

There are two sides of Language which are considered as quite relevant and obligatory and they are from the points of view of its structure and use. That is, it has social and functional significance in its day-to-day use. The significance and relevance are interdependent, as one cannot think of a language without a society by which it is used, and vice versa. Language plays a vital role both in the formal and informal levels and contexts, starting from the home domain. There are at least two styles of language a human being possesses namely, 'careful speech style' and 'casual speech style' and he/she manages by choosing the appropriate one depending upon the contexts ${ }^{3}$.

Language has a well defined structure but for a few exceptions such as

$$
\begin{aligned}
& \text { E.g. go - went (past tense) } \\
& \text { sheep - sheep (sg vs p.no difference) } \\
& \text { sing - sang (past tense) } \\
& \text { mouse - mice (plural) } \\
& \text { you are teacher } \\
& \text { you are teachers } \\
& \text { (use of 'are') etc. }
\end{aligned}
$$

$$
\begin{array}{ll}
\text { Cardinal Number }+ \text { suf. } \\
\\
\text { Four }- \text { fourth } \\
\begin{array}{ll}
\text { (Eng.) } & \text { ten-tenth } \\
\text { (Tam.) } & \text { na:a->ku -> na:naka:m/na:nka:vatu etc. }
\end{array}
\end{array}
$$

But, these languages differ in a number of structures as well. All these structural similarities and distinctive variations/differences have to be explicitly made known to the learners especially in ELT or TLT.

\section{Language Teaching - Learning}

LTL is a good old practice worldwide and a number of methods and practices are being followed with changes and modernization. Teaching a second language - foreign language - other tongue has become a need or necessity since a long time for different purposes. The methods followed are revised or revitalized based on the experience gained by experts and practitioners in different sociolinguistic contexts and situations. The experience - observations thus gained have to be put into research in order to modernize language teaching - learning in general and that of second language teaching in particular. This is because of the extended bi or multilingual use of languages in the present day context. 
Along with these, LTLM has to be modernized by updating and reinforcing the existing language TeachingLearning methods on the one side and adding the component CALL (Computer Aided Language Learning) on the other. This is considered as the current world wide practice in LTLM ${ }^{1}$.

Tamil:

- $\quad$ atu varum 'it will come' $\leftrightarrow$ avai varum 'they will come'

(atu varukiratu 'it comes' $\leftrightarrow$ avai varukinrana) 'they are coming'

- atu varukiratu 'it comes'/varukin?atu $\leftrightarrow$ avai varukin?ana 'they are coming' (and not as avai varukirana)

- $\quad$ pa?ittatu/va?tatu.....

The act of reading/coming etc.

The one who came/read etc.

Though English and Tamil belong to two different language Families, structure wise there are similarities. For example:

- Occurrence of Adj $+\mathrm{N}$ in constructions good boy nalla paiyan

- Occurrence of Intensifier + Adj $+\mathrm{N}$ very good person (English) mika nalla a:? (Tamil)

- $\mathrm{Sg} \rightarrow \mathrm{pl}$ forms (Formation)

$$
\left.\begin{array}{l}
\left.\begin{array}{l}
\text { boy } \rightarrow \text { boys } \\
\text { teacher } \rightarrow \text { teachers } \\
\text { maram } \rightarrow \text { marankal } \\
\text { pu: } \rightarrow \text { pu:kka? }
\end{array}\right\} \\
\text { ? }
\end{array}\right\} \quad \text { (Tamil) }
$$

- beauty $\rightarrow$ beautifu? (English)

a ?aku $\rightarrow$ a? ?aka:na (Tamil)

\section{Components of LTLM}

There are at least four important components viz.

- Content part,

- Methodology,

- Implementation and,

- Evaluation and Feedback

Which need to be strengthened in the process of modernization of Language Teaching - Learning Process. Methods and Materials are considered as vital in the process of LTLM.

Language in general and that of LTLM in particular is context oriented and controlled. It starts from the lexical level of language and goes up to the discourse level in a hierarchical order. This is because starting from the lexical use we assign and associate all types of features with meaning. This meaning concept is divided into three subtypes viz. 1. Lexical meaning, 2. Grammatical meaning and 3. Contextual meaning (including social meaning). We try to relate all types of forms with that of function and meaning (F-Fu-M relationship). A lexical item has one or more meanings in languages.

e.g., call, house, beauty, run, look..... (Eng)

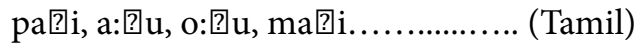

\section{Methodology: Form-Meaning- Function}

That is, all lexical usages in a language enter into larger grammatical formations and used in different morphological-phrasal-sentence formations. Thus they are assigned different grammatical meanings when they occur in grammatical constructions.

\section{Levels}

\subsection{Morphological Level}

Ta. tampi - u?aiya $>$ tampiyu?aiya 'younger brother's' tampi - ka? > tampika? 'younger brothers' o:? $\mathrm{u}$-in -a:n > o:? ?ina:n '(he) ran' avarka? -ai- um $>$ avarka? ?aiyum 'them also'

Eng.

teach

teach - er $>$ teacher

teacher's

Eg.

for the teacher beauty-

about the teacher beautiful

to the teacher beauty - full - ly

beautifully

Ta.

avar, avar - ai, avarukku

avarukku - ta: > avarukkuta:n 'to him' (emph)

>avarukkkuta:n - e: 'to him' (emphasis)

\subsection{Phrase Level}

Eng:

a teacher

about the teacher

told me about the teacher

Ta:

avaruku ko? $\mathrm{u}$ 'give(it) to him' 
en puttakam 'my book'

en puttaka?ta:n 'it is my book' (emph) etc.

atai avarukku ko? $\mathrm{u}$ 'give it to him'

ni: / atai avarukku ko? lu 'you give it to him'

\subsection{Sentence Level}

$\mathrm{He}$ is a teacher

She told me about the teacher

Ta:

avar /e?ka?u?aiya a:ciriyar

avarum e?ka? u?aiya a:ciriyar

avarta:n e?ka?u?aiya a:ciriyar

avarum na:num na? parka?

avarum na:num neru? kiya na? parka?

avarum na:num mika nerunkiya na? parka?

Eng:

John is a teacher

John is our teacher

John is an English teacher

John and Mary are teachers

Tam.

itu periya $\mathrm{pa}$ ? $\mathrm{i}$

na:n intap pa? ?iyil pa?itte:n

$\rightarrow$ itu na:n pa?itta pa国?

'this is the school where I studied'

pa?ittu e? ?tine:n 'I wrote it after reading it'

pa?itta:l 'if (one) reads' / pa?itta:lum 'even if (one)

reads'

pa?itta pa国国 'the school where... studied'

Eng:

He went away.

He went away this morning.

John and Mary are friends.

He went away this morning with his friend.

Socio-functional aspect of language refers to the study of language use in different socio-cultural contexts informal as well as informal domains. Through the structure of language is common and standard for all users the functional aspects are different individuals or language users. That is reason why the functional grammar of a language has to be given due importance in explaining the use of language in different socio-cultural contexts. It is also relevant and needed to explain the social meaning of language. In some contexts are can identify the same grammatical form being used to express two or more contextual meanings.

Example

1. Tamil atu vantatu 'it came'

atu vantucci 'She (younger sister) came'

amma: vantutu 'mother came'

(Close social relationship)

a ? ? ?an ippo vanturum 'elder brother will (come here) now'

2. English It is me

This is Karunakaran

I am Prof.Karunakaran calling from.....

(Human $\leftrightarrow$ Non -human agreement)

Grammatical Form-Function oriented Explanation

In tamil the ovvoru 'each' when it occurs with a (followed by in) has to be immediately by the particle - $\underline{\text { um }}$

Ovvoru a: ciriyarum anntap pa?iyaic

$$
\mathrm{N} \text { part }
$$

Ceyya ve:??

'each teacher has to do (and complete) their work'

Each teacher $\leftrightarrow$ ovvoru a: ciriyarum

Ovvoru na:lum tiruna:Ita:n

'each day is an auspicious day'

But in a context like avarka? ovvoruvara:ka vantha:rka?

'They came (there) one by one'

We find a difference in its function. This is how contextual meaning differs.

So, functional grammar insists the use forms not only based on the grammatical appropriateness, but also their contextual /functional significance.

\subsection{Discourse Level}

\subsubsection{Brief Discourse}

He is John. John came here two days back. He is my good friend. He is an English teacher. He wants to undertake a trip to New Delhi. He requested me to reserve a ticket for his travel. So, I am going to make reservation for his journey this evening. Indeed, it is pleasure for me to assist him.

This kind of discourse provides/brings out the functional importance of noun and verb structures quite explicitly (along with use of adjectives, adverbs and particles).

\subsubsection{Transformations}

Starting from the formation of simple sentence (phrases as well) one can explain the formation of a simple sentence and later on derivation of complex sentences, as well as conjoining of sentences by using conjunctive particles etc. All these substantiate the formation - expansion - transformation of sentences of different types. It is also necessary to explain the sentence formation - coordinate and complex sentences as well as transforming them. 
Eng:

He came here

He came here yesterday

He came here yesterday evening

He also came here yesterday evening

Did he come here?

He did not come here?

When did he come here?

He came here yesterday and went out this morning around 10 a.m.

\subsection{Contextual/Social Meaning}

Language -context -function

The 'Form - function - meaning' and 'language context-function' relationship are slightly different because the semantic aspect of language is context bound in some cases, in spite of the free variation that exists in some other cases.

\begin{tabular}{|c|c|c|}
\hline Tamil & \multirow{3}{*}{\multicolumn{2}{|c|}{$\begin{array}{l}\text { English } \\
\text { you }(\mathrm{sg} / \mathrm{pl}) \text { come here } \\
\text { you }(\mathrm{sg} / \mathrm{pl}) \text { please come here }\end{array}$}} \\
\hline 1) ni: va: & & \\
\hline ni: va:ye:en & & \\
\hline ni:? ?a va:? ka & \multirow{2}{*}{\multicolumn{2}{|c|}{$\begin{array}{l}\text { (or) } \\
\text { 'would you mind coming here' }\end{array}$}} \\
\hline ni:? & & \\
\hline 2) ma:?pumiku(Hon & term) & Mr.President! \\
\hline$\frac{\text { amaiccar avarkaIe! }}{\text { PN+address }}$ & & Honourable President \\
\hline 3) cako:katara & & ladies hostel \\
\hline (mas.) cako:tarika目: & & Gentleman \\
\hline (Feminine) & \multicolumn{2}{|c|}{ (Feminine $)+($ masculine $)$} \\
\hline 4) ni:?kal va:ru?ka? & & you please come \\
\hline $\begin{array}{l}\text { You (hon.sg.) please cc } \\
\text { (no addition) }\end{array}$ & ome & $\begin{array}{c}\downarrow \\
\text { additional f(orm) }\end{array}$ \\
\hline
\end{tabular}

Eng:

You come here

You please come here!

Ta:
ni: va:
ni:? 学a? va:ru? ka?
ni:nka? i?ke: varu?ka?e:n etc.

In a discourse we come across the use of particles. The functional importance of the use of particles with nouns, verbs, adjectives and adverbs has to be explained. There are functions such as request, instruction, question, expansion and transformation to maintain adequate cohesion and coherence in a discourse.

Tamil:

ni: va:

'you(sg) come'

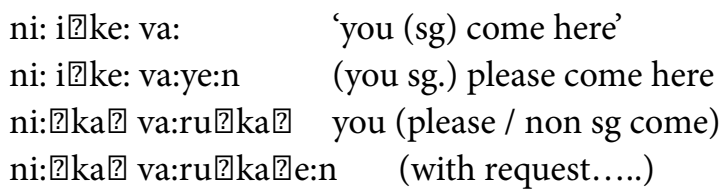

In Tamil the suffix - ? $\mathrm{ka}$ ? is used not only to denote plural as well as honorific meaning. It also brings out the closeness between the speaker and hearer. In a sense, it is a form that denotes politeness and respect.

\section{Social Meaning of Expression}

Illustration: Sentences/Phrases

po:y varuki lo:m (gram meaning) 'we will go and come back'

In the context of leave -taking po:y varuki?o:m/ varuki?o:m means 'let us take leave of you'

In the above illustration we find the use of the verbs po: 'go' and va: 'come'. But, in the context of 'leave taking' and 'leave-giving' we find the use of either both the verbs po: and va: or the use of only va:. The verb po: is either completely avoided or used along with the verb va: (as it relates to leaving once for all from this world). This type of contextual usages conveying the social meaning have to be explained to the second language learners. There are forms such as please, would you like.... / would you mind..../ it is my pleasure, and so on in English carry such social / contextual meanings ${ }^{2}$.

So, it becomes necessary to include such forms and contexts to make language use more adequate and quite efficient in communication.

\section{References}

1. Crystal D.Language Teaching Methods and Practices. OUP:London;2004.

2. Karunakaran K. Standard spoken Tamil(study in diglosia),ann Arbor(USA): Northside Publishers; 2004.

3. Labov W.Social stratification of English in the New York city. Philadelphia: AP; 1966.

\section{Other References}

1. Ferguson CA. Study of language structure and language use. Cambridge: CUP; 1980.

2. Karunakaran K. Sociolinguistic patterns of language use. Annamalainagar: AITLA; 1984. 